\title{
COMMUNITY EMPOWERMENT AT NANGGERANG VILLAGE IN REDUCING POTENTIAL FLOOD THROUGH BIOPORE INFILTRATION HOLE (LRB) TRAINING AND DEVELOPMENT
}

\author{
Ira MULYAWATI \\ Environmental Engineering, Sahid University Jakarta, Indonesia \\ ira.mulyawati@gmail.com
}

\begin{abstract}
Nanggerang Village is one of the seventh villages in the Tajurhalang District, Bogor Regency, Java Province, which often experiences flooding. The decrease in infiltration land due to changes in land use and poor waste management patterns in the area causes flooding to become increasingly threatening. Therefore, there needs to be community empowerment at Nanggerang Village in reducing potential floods through biopore infiltration hole training and development. The first step in this community empowerment activity is to instill an understanding of waste management that corresponds to its type; the following action is by conducting training in making biopore absorption holes as a preventive measure in preventing flooding. The activity was carried out on April 15, 2021, involving ten representatives from each RW in Nanggerang Village. The result of community service is the installation of 10 biopore. Based on the post-test results, the post-test shows that after the extension and training activities, the occurrence of increased public knowledge on waste management and practical theories about biopore infiltration holes, as well as the ability of the community in making biopore infiltration holes.
\end{abstract}

Keywords: Biopori, Flood, Community Empowerment, Infiltration Hole

\section{BACKGROUND}

Climatologically, scientists classify climate patterns in Indonesia into three types: the monsoon pattern, the equatorial pattern, and the local pattern. The monsoon pattern has a characteristic form of rain pattern unimodal (one peak rainy season) During three months of relatively high rainfall, commonly called the rainy season. It is usually called the rainy season for three months of relatively high rain, namely December, January, and February (DJF). Three months of low rainfall can be called the dry season, the period of June, July, and August (JJ). In comparison, the remaining six months is a transitional period (three months of transition from dry to rainy and three months of growth from rainy to dry). These conditions create global warming and climate influences such as rising temperatures and sea levels in Indonesia's territory, which is at the equator. This condition causes a high incidence of natural disasters (BNBP, 2017). One of the natural disasters that often occur in Indonesia is flooding. Heavy rainfall in certain months causes flooding. Flooding is one of the natural disasters that we must be aware of in some areas in Indonesia. West Java Province is one of the areas affected by the flood disaster. Nanggerang Village is one of 7 villages in the Tajurhalang District, Bogor Regency, Java Province, which often experiences flooding almost every year. High rainfall and changes in land use make this area an area that often experiences floods. Land use in Nanggerang Village based on percentages is as follows: rice field area 3\%, Tegal/Ladang $8 \%$, Settlement $61 \%$, Plantation 3\%, public facilities covering 3\%, land/swamp $2 \%$. About $61 \%$ of the land use in Nanggerang village is for housing, while less than $11 \%$ of open green land. This reduced green available land causes the water catchment area in the village of Nanggerang to decrease, and this causes the village of Nanggerang during the rainy season to be prone to flooding.

At the beginning of 2020, all areas of Bogor Regency, especially Nanggerang Village, Tajurhalang District, did not escape the high rainfall that fell. Garbage that clogs some sewers causes inundation, in addition to the sewers that are too small on the road connecting Nanggerang Village with Sasak Panjang Village also caused flooding The community in Nanggerang Village still lacks awareness about the importance of maintaining environmental cleanliness, lack of knowledge about waste management by type, and lack of public knowledge about the application of appropriate technology as a preventive measure in preventing flooding. For this reason, it is necessary to hold outreach on the importance of maintaining cleanliness, waste management by type, and training on waste management by type.

\section{METHODS}

Implementation Method The settlement method used in this Community Service activity is arranged in several stages, namely:

1. Handover of tools to make biopore infiltration holes, Figure 1 and Table 1.

2. Counseling on the importance of keeping the surrounding environment clean and waste management based on the type of waste. Counseling is done by resource person on April 15, 2021 (Figure 1).

3. Providing materials and practices on applying appropriate biopore technology as a preventive measure to prevent flooding. The community is given a module on practical theory and stages in making biopore holes. Biopore holes practice was conducted on 15 April, 2021 after the training activities (Figure 2). The steps in making biopore holes include the following:

- Before starting to make biopore, first determine the location used as a place of manufacture.

- After we determine the place to install biopore hole infiltration, then flush the soil that will be used as a place to make biopores with water so that the ground becomes softer and easier to hole. 
- Make holes in the soil using a soil drill; try to make a vertical one.

- Make a hole with a depth of approximately 1 meter with a 10-30 cm diameter, Figure 3.

- After that, line the hole using a PVC pipe whose size is the same as the diameter of the hole.

- Then, fill the hole with organic waste such as leaves, grass, fruit peels, and garbage coming from other plants. After that, close the hole using iron wire or use the pvc pipe cap that we have hole first.

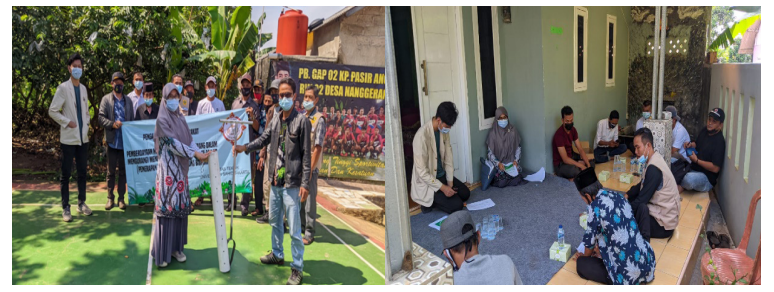

Figure 1. Handover of tools to make biopore infiltration holes, \& Counseling on the importance of waste management by type and providing practical, theoretical material for making biopore holes

Table 1. Biopore Hole Infiltration Materials and Tools
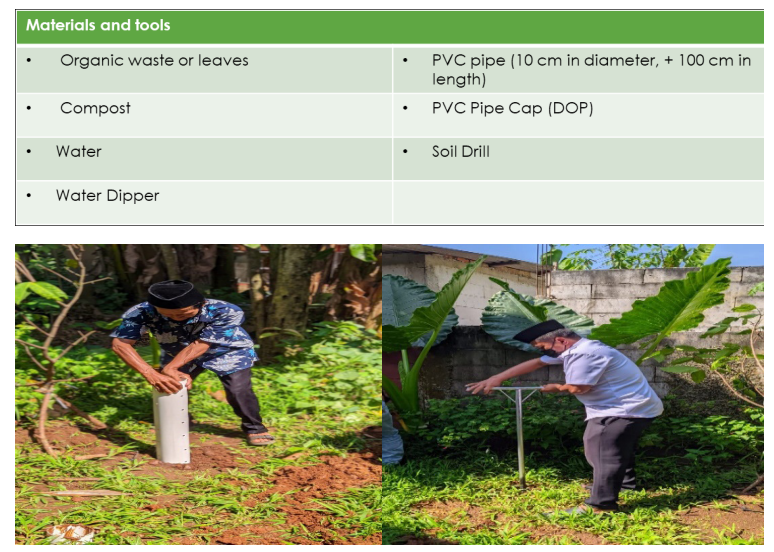

Figure 2. Practical training of making biopore holes

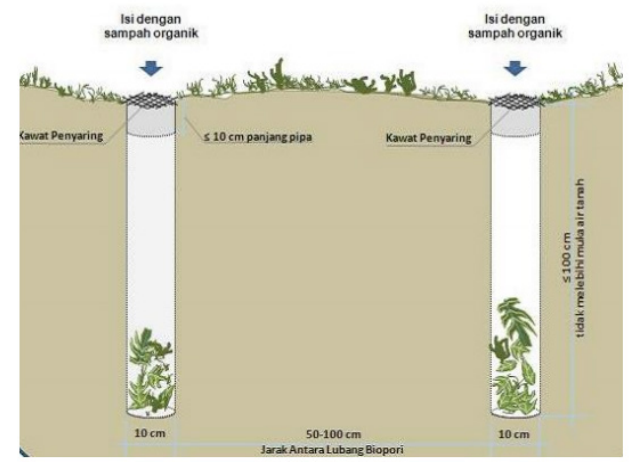

Figure 3. Biopore Infiltration Hole

Source: http://sda.pu.go.id/bwssulawesi2/cara-membuat-biopori

\section{RESULTS AND DISCUSSION}

\section{Result}

Counseling activities and practical training on making biopore holes, it was carried out one day, on April 15,2020 . Before the action was carried out, all participants filled out the Pre Test, ten people, and filled out the posttest after the activity. The following are the questions given to the participants: (1) Which of the following statements about waste do you think is true? ; (2) What do you know about the types of waste? ; (3) What are the impacts of garbage that are not managed by the community properly?; (4) In your opinion, what is the correct way to treat waste? ; (5) Have you ever heard of biopore?; (6) What do you know about biopore technique?; (7) What are the materials used to make biopore? ; (8) In your opinion, where is the right location for making biopori?; (9) What are the benefits of biopore?. The community service team then carried out item analysis by correcting correct and incorrect answers to find out questions with a relatively low percentage of correct answers. The question items from 9 pre-test questions are as many as $40 \%$ of partners who answer correctly on the types of garbage. As many as $50 \%$ of partners answer correctly on waste management.

Furthermore, $50 \%$ of partners correctly answer biopore techniques, materials in making biopore, locations for the manufacture of biopore, and the benefits of biopore. For post-test results obtained is participants answer $100 \%$ correctly on each item of the question. Furthermore, $50 \%$ of partners answered correctly about the biopore technique, the material in making biopore, the location for making biopore, and the benefits of biopore. For the posttest, the results obtained were that participants answered $100 \%$ correctly on each question item (Figure 3).
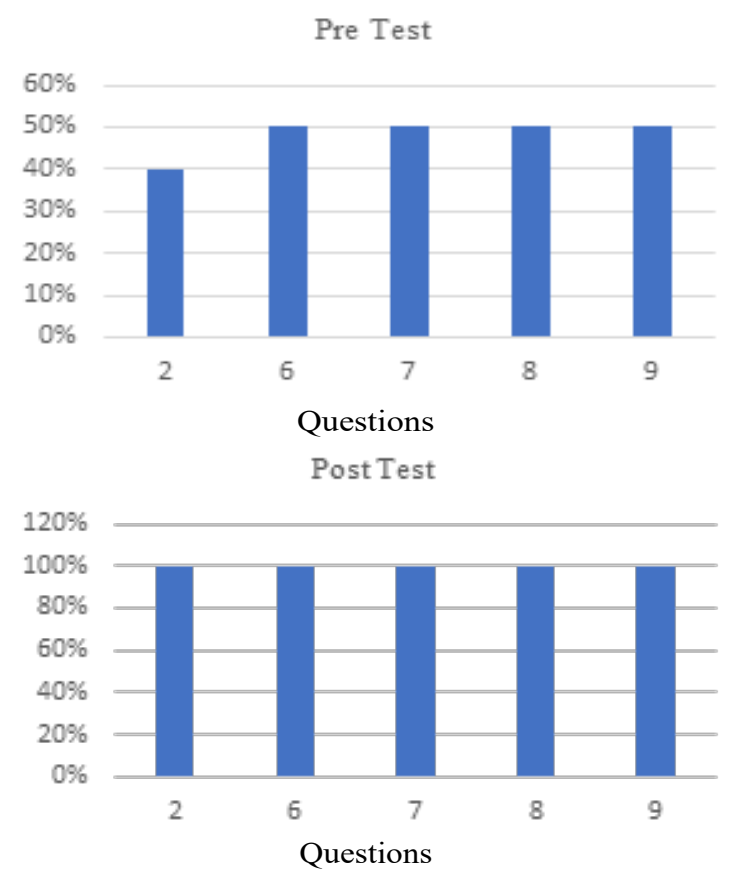

Figure 3 Pre-Test and Post-Test Results

After conducting counseling and training, the next step is the evaluation stage. This evaluation stage was carried out for three months to see the effectiveness of the biopore infiltration hole to reduce inundation during the rainy season and to see the fertilizer yield from the biopore infiltration hole (Figure 4). Biopore infiltration holes have been installed ten, five of them installed in one location that has great potential during flooding, then five of them are installed in each RW. 
At the evaluation stage of the community service team made a WhatsApp group of trainees. Participants will report an evaluation of the biopore holes every two weeks. Based on the evaluation results reported by participants for three months, biopore holes are effective enough to reduce inundation when rain occurs. In addition, compost from biopore holes has matured after three months.

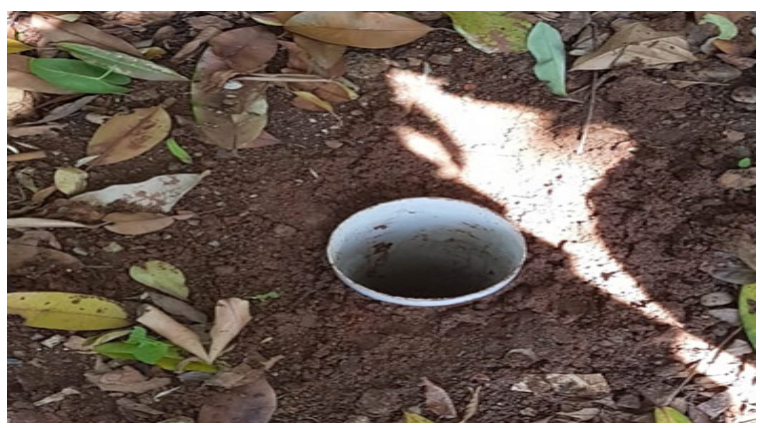

Figure 4 Post-Rain Biopore Infiltration Hole Conditions

\section{Discussion}

In the results section, it has been mentioned that the Biopore infiltration holes have been installed ten, five of them installed in one location that has great potential during flooding, then five of them are installed in each RW. Our hope from this community service activity is that each RW will train each RT and then each RT will train the community to make biopore infiltration holes, but this has yet to be implemented. The result of three months of evaluation, knowledge related to the practice of making biopore holes has not yet been widely disseminated in the community. This is because of the Covid-19 pandemic, which is increasing in cases in the village of Nanggerang, so that community activities are limited.

\section{CONCLUSION}

The conclusions that can be drawn from this training activity are:

1. The counseling and training has increased the interest and knowledge of the community to manage waste according to its type and apply biopore infiltration holes to prevent flooding.

2. The community is more concerned about the surrounding environment and tries to keep their environment clean and free from the garbage.

3. The community realizes that there is simple technology with easily available tools and materials to prevent flooding.

\section{ACKNOWLEDGEMENT}

We would like to thank Sahid University Jakarta who has provided opportunities and funding to realize this community service. We also express our gratitude to the Head of Nanggerang Village, Tahurhalang District, Bogor Regency, and the people of Nanggerang Village. They have given permission and participated in the implementation of community service.

\section{REFERENCES}

Badan Pusat Statistik. 2017. Kecamatan tajur halang Dalam Angka. Jakarta : BPS.

Diana, P., Supriyanto, S., Bambang, H., S., Basuki, W., Prijanto, P. 2015. Aplikasi Lubang Resapan Biopori Dan Cross Drain Untuk Rehabilitasi Di Jalan Sarad. Jurnal Penelitian Hutan dan Konservasi alam Vol. 12 , No. 2

Edo, (2019) Analisis Banjir dan Pemetaan Kawasan Terdampak Banjir di kelurahan Laweyan, Kota Surakarta

Elesvera D., Hartuti P., Syafrudin S.2015. Evaluation on Sustainability of Technological Dimension Biopore Absorption Hole Management for Soil Water Conservation in Semarang City. Journal of Soil Science and agroclimatology Vol 12, No 1

Halauddin, H., Suhendra S., Refrizon R., Fachri F. 2016. Pemanfaatan Lubang Resapan Biopori (LRB) dan Perhitungan Permeabilitas Untuk Setiap Titik Lubang Resapan Di Rawa Makmur Permai Bengkulu. Jurnal Ilmiah MIPA Vol 12, No 1

Mulyaningsih, T. 2014. Status Keberlanjutan Ekologi pada Pengelolaan Lubang Resapan Biopori di Kelurahan Langkapura Kecamatan Langkapura Kota Bandar Lampung. Jurnal Sains Tanah Volume 11 No 2 Tahun 2014.

Murti, J. Efektivitas Lubang Resapan Biopori terhadap Laju Resapan (Infiltrasi). 2013. Jurnal Teknologi Lingkungan Lahan Basah

Pembuatan Lubang Resapan Biopori Sebagai Alternatif Penanggulangan Banjir Di Kelurahan Maharatu Kecamatan Marpoyan Damai Pekanbaru. 1, 5.Hariyanto, S. (2019).

Poedjowibowo, Djajeng. 2011. Infrastruktur Limbah Terpadu Dalam Taman Lingkungan Permukiman. Jakarta : Jurnal Landskap Indonesia, 2011, Vol. 3 No. 2. 